\title{
THE ROLE OF SOCIAL MEDIA IN E-GOVERNMENT: SYSTEMATIC LITERATURE REVIEW AND CASE OF JORDAN
}

\author{
Nemer Aburumman and Róbert Szilágyi ${ }^{1}$
}

DOI: $10.24989 /$ ocg.338.29

\begin{abstract}
Social media has become a new revolution in communications and most governments around the world use these platforms as two-way communication between them and the citizens. The Jordanian government started using these platforms early, so this paper came to examine the Jordanian's practice on these platforms. The paper use two way of analysis, the first one was a systematic literature review in the largest two databases (Scopus and Web of Science). After the literature has been analysed and the paper found the best practices for governments around the world, three main determinants were identified for any government to start the use of social media (presence, up to date information and interaction). The most popular Jordanian's social platforms (Facebook, Twitter, and YouTube) have been selected to start the analyses and 52 Jordanian governmental institutions (all the 25 ministries and 27 institutions belong to the prime ministry) have been analysed. After the institutions' websites and their pages or accounts on social media platforms scanned and analysed, most of the institutions have fulfilled the first two criteria (presence) and $77 \%$ shows that they have appearances on social media and (up to date information) $67 \%$ of the institutions regularly updated their information. But for the last criteria (interaction) we have found that the institutions still need to improve their interactions with the citizens since the results showed only $38 \%$ of these institutions have interaction on their pages or accounts on social media.
\end{abstract}

Keywords : E-Government, Social Media, Citizen Engagement, Jordan, Facebook, Twitter, IT Management

\section{Introduction}

Alongside with the creation of new ways for governments to enhance serving their citizens and businesses through the internet (Nations, 2014), a revolution in governments' use of the internet took place in order to deliver services to their stakeholders. During the 1980s and 90s, the Information and Communication Technology (ICT) revolution had an impact on everyday activities, but moreover, transformed the extent to which governments interact with their citizens. From the mid-1990s, both public and private sector organizations have engaged in finding the best ways to take advantages of the new technologies to provide their services in order to develop their relationship with their stakeholders. In general, the private sector was more proactive in embracing ICT as a mean of communicating, interacting and transacting, whereas governments were initially cautious (Jaeger \& Thompson, 2003). But, as Jaeger (2003) observes, this initial caution dissipated quite quickly and by the early 2000 s, many governments had initiated e-Government projects: a decade ago, even the most

\footnotetext{
${ }^{1}$ Doctoral School of Management and Business, University of Debrecen, Hungary.
} 
technologically aware experts probably would have found the state of e-government in 2003 to be surprisingly robust (Grönlund, 2010).

There are many different definitions of e-Government in the literature, but they all include the concept of the use of technology by government or public sector organizations to serve their stakeholders (which span citizens, business, and public sector organizations, to other agencies within the government). For example, World Bank defined it as the government agencies use of information technologies (such as, the internet, and mobile computing) that have the ability to transform relations with citizens, businesses, and other arms of governments. These technologies can serve a variety of different ends: better delivery of government services to citizens (Sarrayrih \& Sriram, 2015).

However, as mentioned earlier, despite the diversity of e-government definitions found in the literature, there is a common central concept that underlies all these definitions - the usage of webbased tools and applications for public service delivery (Rumman \& Szilágyi, 2018).

\subsection{Social media}

Social media is defined as online tools and utilities that allow communication of information online, participation and collaboration such as blogs, microblogs (i.e., Twitter), social sharing services (e.g., YouTube), text messaging, discussion forums, collaborative editing tools (e.g., wikis), virtual worlds, and social networking services (e.g. Facebook, LinkedIn) (John Carlo Bertot, Jaeger, \& Hansen, 2012; Clark, Algoe, \& Green, 2018).

In the beginning of the 2000s more social media platforms started to appear on the surfaces such as Myspace and LinkedIn and a few years more websites joined like YouTube, Facebook, and Twitter. In 2007 'Facebook' developers upgraded the application to be more interactive, which allows users to participate and interact more by making comments and creating content which made the users of this application increase in a huge way (Boyd \& Ellison, 2007). Since then, social media platforms kept developing their websites and made it more flexible, user-friendly and interactive, all that made the number of the viewers, surfers, and the accounts created become a new revolution.

The use of social media websites has dramatically increased in the past few years as we mentioned before, and nowadays it plays a major role in people's social life. By the end of 2010, there was nearly one billion social media users in the world and this number is expected to jump by nearly $300 \%$ by the end of 2020 to reach near 3 billion users (Statista, 2019). Social media has become a wide path for dialogue, expressing opinions, communication with others and exchanging news and information. As a result of the user's huge tendency to the use of these social media platforms and because these platforms became very important, the governments around the world became more aware of the role of these websites and platforms, and at the end, using these websites become essential to keep pace with the user's new tendency.

\section{Theoretical background and lessons from other countries}

Systematic Literature Review was adopted to restrict the existing literature, to explore the research trends in this field and best practices for governments in using social media. In this study, 2 search engines were used (Scopus and web of Science databases). 
First, a search was carried out using keywords related to the topic, the keywords were ( "egovernment" or "electronic government " and "social media" or "social network" ) as a result to this first search 25,729 articles were found (Scopus 415 and Web of science 25,314) .

After the first search and to minimize the result and get more related results, secondly the keywords have been changed to be "e-government and social media" OR "social media and e-government" OR "social network and e-government" OR "social media and electronic government " OR "social network and electronic government", Third the results limited for the last 10 years to get the most recent articles.

After this step, the number of studies reduced to 30 studies (21 on Scopus and 9 on Web of Science). The results are called candidate Studies. The final step was selecting and filtering the candidate studies based on excluding the book chapters and conferences and secondly a comprehensive review of all the candidate studies and choosing the studies that directly related to the research topic, the studies after this systematic search finalized to 16 studies selected to be analysed for this paper and the summary of the analysed articles shown in Table 1.

\begin{tabular}{|c|c|c|}
\hline Author/ year & Title & Main findings \\
\hline $\begin{array}{l}\text { Alryalat, Rana, } \\
\text { Sahu, Dwivedi, } \\
\text { \& Tajvidi, (2019) }\end{array}$ & $\begin{array}{l}\text { Use of Social Media in Citizen- } \\
\text { Centric Electronic Government } \\
\text { Services: A Literature Analysis }\end{array}$ & $\begin{array}{l}\text { This paper presented a comprehensive review of all } \\
\text { literature related to e-government and social media to find } \\
\text { the main topics that combined the two terms in the } \\
\text { literature, the paper found that the most used topics used } \\
\text { in this field were electronic participation, transparency, } \\
\text { interaction, safety, and cooperation. } \\
\text { Many studies have mentioned the importance of social } \\
\text { media in e-government and identified it as a powerful tool } \\
\text { for the governments. Using it can be easily disseminated } \\
\text { to the citizens who usually don't participate in government } \\
\text { decisions and policies. }\end{array}$ \\
\hline Ma, (2016) & $\begin{array}{l}\text { Government Website, Social Media, } \\
\text { and Citizens' Perceptions of } \\
\text { Corruption: Evidence from Chinese } \\
\text { Cities }\end{array}$ & $\begin{array}{l}\text { In this study, they explored the relationship between the } \\
\text { use of social media platforms, e-government, and the } \\
\text { citizens' perceived corruption. It was conducted in } 36 \\
\text { Chinese cities and concluded that there is an impact of the } \\
\text { social media platforms use on corruption perceptions. }\end{array}$ \\
\hline $\begin{array}{l}\text { Porumbescu, } \\
\text { (2017) }\end{array}$ & $\begin{array}{l}\text { Linking public sector social media } \\
\text { and e-government website use to } \\
\text { trust in government }\end{array}$ & $\begin{array}{l}\text { This study was conducted in South Korea on } 1100 \text { citizens } \\
\text { to see if there is a relationship between the use of e- } \\
\text { government websites or social platforms and the citizen's } \\
\text { trust and satisfaction. } \\
\text { The study connected that the use of traditional websites is } \\
\text { negatively related to the trust and satisfaction of citizens, } \\
\text { unlike social platforms that are positively linked to the } \\
\text { satisfaction and trust of citizens. }\end{array}$ \\
\hline $\begin{array}{l}\text { Didik } \\
\text { Madyatmadja \& } \\
\text { Julio Kiswanto, } \\
\text { (2019) }\end{array}$ & $\begin{array}{l}\text { Social media-based e-government } \\
\text { application feature }\end{array}$ & $\begin{array}{l}\text { The study was conducted in Indonesia in } 9 \text { cities on the } \\
\text { applications for e-government if they contain features of } \\
\text { social platforms such as (Realtime chat, sharing... etc.) } 24 \\
\text { characteristics were identified from the literature. } \\
\text { This study found that e-government can build applications } \\
\text { based on social media platforms or their features. }\end{array}$ \\
\hline
\end{tabular}




\begin{abstract}
Chaieb, Achour, E-government and social media in \& Ferchichi, (2018) Tunisia: An empirical analysis (2018)

Gao \& Lee, $\quad$ E-government services and social (2017) media adoption: Experience of small local governments in Nebraska state

This study was conducted in Tunisia on some government agencies' pages on Facebook, the paper reviewed the way government agencies use the social media platforms and the way Tunisian citizens interact on these pages.

The results show that this use is limited to providing information and news and does not actually take advantage of the social media provided to lead discussions, stimulating discussions that can lead to better citizen engagement.

The results also showed that citizens are interested in government decisions. For this reason, it is important for these agencies to develop methodological and technological changes to make the best use of these social platforms, in order to encourage citizens to participate more.

This study was conducted in the United States /Nebraska to explore the relationship between e-government services and social media adoption by small local governments.
\end{abstract}

The study found that Facebook is used more for egovernment transaction services and on the other hand Twitter used more with the information services.

\begin{tabular}{|l|l|}
\hline Bosch, (2017) & $\begin{array}{l}\text { Use of social media and e- } \\
\text { Government in disasters: } 2016 \\
\text { Louisiana floods case study }\end{array}$ \\
& \\
\hline $\begin{array}{l}\text { Porumbescu, } \\
\text { (2017) }\end{array}$ & $\begin{array}{l}\text { Linking Transparency to Trust in } \\
\text { Government and Voice }\end{array}$ \\
\hline
\end{tabular}

This study was conducted in Louisiana / United States of America and this study explores the way of using social media platforms to communicate with government agencies in disasters.

30 users were surveyed after Louisiana Floods in 2016 and found that the use of these platforms increases in disasters and they use them mainly to locate the family, ask for help and share information. but most surveyed users did not use these platforms to communicate with government agencies, and the results showed that most of the participants were dissatisfied with the use of government agencies for these platforms during disasters.

This study measures how the use of social media and traditional e-government websites affects the trust and transparency in government.

The study concluded that the use of social platforms greatly affects government trustworthiness and transparency more than the use of traditional websites of e-government.

Vicente \& Novo, (2014)

An empirical analysis of eparticipation. The role of social networks and e-government over citizens' online engagement
This study was conducted in Spain on secondary data from a survey conducted in 2011 on the use of information and communications technology and E-participation (reading, expressing opinions about social and political issues, sharing and public consultations).

The results showed that E-participation is mainly related to the skills of using the internet and that there is a large gap between gender with electronic participation. Finally, 


\begin{tabular}{|c|c|c|}
\hline & & $\begin{array}{l}\text { the E-participation of unemployed people is more than the } \\
\text { rest of the population. }\end{array}$ \\
\hline $\begin{array}{l}\text { Kawtrakul et al., } \\
\text { (2012).) }\end{array}$ & $\begin{array}{l}\text { Improving disaster responsiveness } \\
\text { using a mix of social media and e- } \\
\text { government }\end{array}$ & $\begin{array}{l}\text { This paper examined the governmental response to natural } \\
\text { disasters using social media platforms. } \\
\text { The paper emphasized the importance of using social } \\
\text { media in unexpected circumstances, such as disasters, by } \\
\text { sharing and receiving information quickly and directly } \\
\text { from citizens, and finally } \\
\text { The paper suggested a model for the optimal use of social } \\
\text { media by the government during disasters to improve } \\
\text { response for disasters. }\end{array}$ \\
\hline $\begin{array}{l}\text { Unsworth \& } \\
\text { Townes,( 2012) }\end{array}$ & $\begin{array}{l}\text { Social media and e-government: A } \\
\text { case study assessing Twitter use in } \\
\text { the implementation of the Open } \\
\text { Government directive }\end{array}$ & $\begin{array}{l}\text { This study was conducted in the United States of America } \\
\text { to explore the united stat Department of Agriculture's use } \\
\text { of social media and if this use supports the three goals of } \\
\text { the open government. } \\
\text { The study concluded that social media channels are the } \\
\text { most important channels for communicating with the } \\
\text { public to achieve the goals of the open government, and } \\
\text { the paper indicated that the three pillars of open } \\
\text { government (transparency, cooperation, and } \\
\text { participation) still need to be expanded to include the } \\
\text { interactions that occur on social media platforms. }\end{array}$ \\
\hline $\begin{array}{l}\text { Camay, Brown, } \\
\text { \& Makoid,( } \\
\text { 2012) }\end{array}$ & $\begin{array}{l}\text { Role of social media in } \\
\text { environmental review process of } \\
\text { national environmental policy act }\end{array}$ & $\begin{array}{l}\text { This study considered the use of social media in the } \\
\text { environmental review pross of transportation projects, and } \\
\text { the study examined three cases. } \\
\text { The study concluded that these platforms allow } \\
\text { professionals working in transportation to interact with } \\
\text { the public on a wider scale. The study presented several } \\
\text { recommendations for the professionals in the } \\
\text { transportation sector and finally recommended more } \\
\text { research to measure the success of informing and } \\
\text { engaging the public more effectively. }\end{array}$ \\
\hline $\begin{array}{l}\text { John C. Bertot, } \\
\text { Jaeger, \& } \\
\text { Grimes, (2010) }\end{array}$ & $\begin{array}{l}\text { Using ICTs to create a culture of } \\
\text { transparency: E-government and } \\
\text { social media as openness and anti- } \\
\text { corruption tools for societies }\end{array}$ & $\begin{array}{l}\text { This paper examines the relationship between the use of } \\
\text { e-government and social media platforms and } \\
\text { transparency and reduce corruption. } \\
\text { The study concluded that previous efforts and studies of } \\
\text { the ability to use technology to create substantive social } \\
\text { change in attitudes towards transparency in particular - e- } \\
\text { government and social media platforms - were not widely } \\
\text { and sufficiently considered. } \\
\text { The study identified some recommendations to increase } \\
\text { transparency through social media platforms such as } \\
\text { (expanding ICT access, increase the trust in ITC and } \\
\text { government, empowering citizens to participate) and } \\
\text { finally mentioned some challenges such as (Technology } \\
\text { literacy, usability, and accessibility) }\end{array}$ \\
\hline
\end{tabular}




\begin{tabular}{|c|c|c|}
\hline Shah (2010) & $\begin{array}{l}\text { Increasing e-Government Adoption } \\
\text { through Social Media: A case of } \\
\text { Nepal. }\end{array}$ & $\begin{array}{l}\text { This study conducted in Nepal and measured the } \\
\text { effectiveness of the government's past communication } \\
\text { outreach efforts and also investigates the possibilities of } \\
\text { using social media to enhance citizen's trust., and the } \\
\text { study found that governments operate in a centralized, } \\
\text { hierarchical manner, while social media allows } \\
\text { governments to contact citizens in a different way than } \\
\text { any time before. }\end{array}$ \\
\hline $\begin{array}{l}\text { Bonsón et al. } \\
\text { (2012) }\end{array}$ & $\begin{array}{l}\text { Local e-government } 2.0: \text { Social } \\
\text { media and corporate transparency in } \\
\text { municipalities }\end{array}$ & $\begin{array}{l}\text { Conducted an overall view about the use of social media } \\
\text { tools in EU local governments in order to determine } \\
\text { whether local governments are using these technologies to } \\
\text { increase transparency and e-participation. } \\
\text { Bonsón also showed that most local governments are } \\
\text { using social media tools to enhance transparency but, in } \\
\text { general, the concept of corporate dialogue and the use of } \\
\text { Web } 2.0 \text { to promote e-participation are still in their } \\
\text { infancy at the local level. }\end{array}$ \\
\hline Magro (2012) & $\begin{array}{l}\text { A Review of Social Media Use in E- } \\
\text { Government }\end{array}$ & $\begin{array}{l}\text { This paper reviewed the literature focused on social } \\
\text { networking applications and social media activities used } \\
\text { by citizens and government to communicate for the five } \\
\text { years (2007-2012) and he found that more work on social } \\
\text { media and e-government policies is still needed since the } \\
\text { use of these technologies is changing rapidly. } \\
\text { Government regulations have been traditionally slow to } \\
\text { catch up with the information age, so more future research } \\
\text { on social media in e-government is needed in the areas of } \\
\text { objectives and strategy, categorization of e-government } \\
\text { applications, and policymaking. }\end{array}$ \\
\hline
\end{tabular}

Table 1: Literature review (Scopus and Web of Science)

Source: Authors edit

\subsection{Summary of Previous Literature}

Social media platforms provide support to the previous view that social media adoption is another step-in e-government evolution (Gao \& Lee, 2017)

Some governments already adopted new policies and started communicating with the citizens through social media platforms and are doing more activities on these websites, such as announcing the services they provide, gaining the support for their policies that have been adapted and getting feedback on a lot of cases and services that will be applied in the future. But unfortunately, the number of governments that use social networks as a facility to do all the jobs mentioned before are still below expectations internationally (M.H. Btoush, 2014; Khasawneh \& Abu-Shanab, 2013; Shah, 2010).

Social media platforms provide the government with direct contact with the audiences and get closer to them and this can give the citizen the feeling of being close to decision makers and break routine and psychological boundaries between the citizen and the government.

Finally, many previous studies found that the use of social platforms may positively affect Eparticipation, transparency and trust (Bonsón et al., 2012; Chaieb et al., 2018; Porumbescu, 2017; Shah, 2010; Unsworth \& Townes, 2012; Vicente \& Novo, 2014), and can also contribute to reducing corruption (John C. Bertot et al., 2010; Ma, 2016). On the other hand, a few studies have identified 
some challenges for using these platforms such as privacy, internet access, and technological empowerment (John C. Bertot et al., 2010). Finally, these platforms managed by external entities that governments do not have control of or access to which increases their fears to use it in a wide way.

\subsection{Jordan}

Jordan is a unique case study because the importance of social media has increased in the Arab world in general and in Jordan in particular after 2011 and that's due to the role that these websites played in what is called "Arab spring" that took place in the region. The use of these platforms has contributed to major changes in various fields (political, social and economic), and the number of users of these platforms started increasing dramatically since that date. Moreover, The UN report showed a significant decline in e-participation index in Jordan, as Jordan ranked 117 out of 193 countries in the world, which is a very low level (Nations, 2018).

In addition, today more than $60 \%$ of the population in Jordan appear on social media platforms (We Are Social, 2017). Most of them are active on Facebook, Twitter and YouTube (around 5,300,000 active users on Facebook and 400,000 on Twitter in 2017 (internet world stats, 2017).

Despite this importance, the research on this topic in Jordan is still limited and needs more work (M.H. Btoush, 2014; Khasawneh \& Abu-Shanab, 2013). Here this paper used the keywords mentioned earlier with new keyword added this time (" Jordan") in 3 search engines (Google Scholar, Scopus, and Web of Science), and after analyzing all the possible articles, only two articles were found directly related to the topic in Jordan (Table.2) .

\begin{tabular}{|l|l|l|}
\hline \multicolumn{1}{|c|}{ Author/ year } & \multicolumn{1}{c|}{ Title } & \multicolumn{1}{c|}{ Main findings } \\
\hline Btoush (2014) & $\begin{array}{l}\text { Government's presence on social media } \\
\text { a study with special reference to Jordan }\end{array}$ & $\begin{array}{l}\text { this research conducted a comprehensive review of } \\
31 \text { Jordanian governmental websites to find the } \\
\text { presence of governments on social media websites, } \\
\text { and he found that the Jordanian government } \\
\text { presence is still not making full utilization of the } \\
\text { potentials social media can offer, moreover, he } \\
\text { mentioned that this presence was so shy and most } \\
\text { of it was limited to provide information. }\end{array}$ \\
\hline $\begin{array}{l}\text { Khasawneh and } \\
\text { Abu-Shanab (2013) }\end{array}$ & $\begin{array}{l}\text { E-Government and Social Media Sites: } \\
\text { The Role and Impact. }\end{array}$ & $\begin{array}{l}\text { They took one page on Facebook (Jordanian e- } \\
\text { government page) as a case study and they did a } \\
\text { content analysis for this page to check the level of } \\
\text { engagement and interaction by citizens. They } \\
\text { found that it has a good level of engagement, where } \\
\text { citizens interact positively with the posts published } \\
\text { by the page through making a like, comment, } \\
\text { share, answering a question or just seeing the page. }\end{array}$ \\
\hline
\end{tabular}

Table 2: Articles about Jordan

Source: Authors edit

All these factors make this case study special and important and can give useful results for the Jordanian government and similar countries. Hence, many researchers were invited to study and explore the current situation of the government's use of social media platforms, especially in this region (references) . 
In addition, they mentioned that social media can allow governments to have the capacity to rebuild the relationship with their citizens and increase the level of citizens' engagement which can reflect on the citizen's trust and involvement in making policies.

Most of the literature mentioned before showed how important for the governments to consider these means in their plans and how important that governments use these websites to promote their policies or plans and to interact with citizens and finally showed a lack of research in this area, especially in the developing country.

Therefore, most previous studies concluded that the widespread use of social platforms such as (offering services and using the features of these platforms) still needs more studies from many aspects (policies, technological and economically), but this analysis concluded, that governments should use these platforms in three basic levels: presence, update information and interaction.

Therefore, these three levels represent the basic use of social media platforms for any government and keeps them away from the risks that the previous studies mentioned such as privacy, control of these platforms, security, etc. Hence, this paper has adopted these three main basic levels of government use of social platforms to explore the current situation of the Jordanian government, the main goal of this paper is to conduct a content analysis for the Jordanian government pages or accounts on three main social media websites that the Jordanian citizens use (Facebook, YouTube, and Twitter).

\section{Materials and methods}

After the systemic comprehensive literature review that has been conducted before for the latest research related to this topic and reviews of other countries experiences, this paper identified three basic and safe levels of the use of social platforms by any government, which are presence, information update, and interaction.

The analysis contains the three levels, first if these governmental institutions have any presence on these three websites and secondly if they update their information and lastly if there is any level of interaction with the citizens on these websites.

This research is based on content analysis of the three main social media platforms used by the Jordanian (ministries and institutions belong to the prime ministry). The research is conducted between the end of June and the end of December 2019.

Therefore, this study is mainly concerned with the citizen's interaction and engagement with the Jordanian government's social media platforms. So, this study we will evaluate the Jordanian government use of social media websites based on three indicators: presence, up to date information and interaction, as the following :

\subsection{Presence}

As Btoush (2014) pointed out, an increase use of social media is the solution to the low participation of citizens in the decision making process and as a start to use these platforms presence is the first stage, in which an official online government's existence is established on one of the social media platforms (pages, accounts or YouTube channel). For this study, we would like to validate this indicator by checking the social media links, tools, and platforms on all governmental institution's 
websites, in other words, if the governmental institution is present on the social media websites that we have selected.

\subsection{Up to date information (UTD)}

This is also an important indicator in social media. Nowadays the users are always interested in new information. UTD has been defined in many ways in literature and it is a diminution of information quality. Information quality is defined as information that is good, useful, current, and accurate (Ovais Ahmad, Markkula, \& Oivo, 2013)(Lee \& Levy, 2014).

For this study, we will check one aspect of the quality of information 'current' or if it is up to date. Therefore, we will check all the information that the institutions shared (posts, tweets or videos) on their pages or accounts on social media and we will see the frequency and the date of last information was published considering it (up to date information) if it is useful information and the date of the information is within 10 working days.

\subsection{Interaction}

United Nations survey defined it as the interaction between citizens, government organizations, public, and elected officials (Nations, 2014). The social media sites provide a new way of interactions between the government and their citizens. These websites allow the citizen to contact directly with the government and get information easily and fast. This is more important, as social media provides new, additional avenues for the delivery of government's information and other public services. For this study to check the government interactions we have sent a question (\{Hello, I have a question. Can I contact you through this page? Or is there another way to communicate? Thanks) to all the governmental pages or accounts and wait for the whole period that we conducted this paper and see how many of the institutions respond to check the interaction.

Finally, as a summary, this process went through four main steps:

Step 1: check all the 52 institutions websites trying to find any links or tools for the three selected social media websites (Facebook, Twitter, and YouTube) (presence) .

Step 2: scan the three selected social media websites trying to find an appearance for the governmental institutions by writing the name of the institution in both languages (English-Arabic) (presence).

Step 3: analyze the social media platforms content and check the information that institutions have published if it is up to date or not (within 10 working days) (up to date).

Step 4: Finally, send a question for the institutions who have existence on social media and wait for their response (from Jun until the end of December 2019) to check the level of interactions (interaction).

\section{Results}

After the two months of content analyses for the social media websites applying the four research steps that we described in the last section, we created a table to show the results. As we can see below, we used the following scoring method. Number one (1) if the institution has fulfilled the indicator criteria or number zero (0) if not and the last column for the sum for each institution. 


\begin{tabular}{|c|c|c|c|c|c|c|c|}
\hline & \multirow{2}{*}{$\begin{array}{c}\text { Jordanian governmental } \\
\text { institutions }\end{array}$} & \multicolumn{3}{|c|}{ Presence* } & \multirow{2}{*}{$\underset{* *}{\text { UTD }}$} & \multirow{2}{*}{$\underset{* * *}{\text { Interaction }}$} & \multirow[t]{2}{*}{ Sum } \\
\hline & & Facebook & Twitter & YouTube & & & \\
\hline 1 & General Intelligence Department & 0 & 0 & 0 & 0 & 0 & 0 \\
\hline 2 & The Audit Bureau of Jordan & 1 & 0 & 0 & 0 & 0 & 1 \\
\hline 3 & Civil Service Bureau & 1 & 1 & 1 & 1 & 1 & 5 \\
\hline 4 & Legislation and Opinion Bureau & 0 & 0 & 0 & 0 & 0 & 0 \\
\hline 5 & Jordan investment commission & 1 & 1 & 0 & 1 & 1 & 4 \\
\hline 6 & Jordan Atomic Energy Commission & 1 & 0 & 0 & 0 & 0 & 1 \\
\hline 7 & Media Commission & 1 & 0 & 0 & 1 & 1 & 3 \\
\hline 8 & $\begin{array}{l}\text { Integrity and Anti-Corruption } \\
\text { Commission }\end{array}$ & 1 & 1 & 1 & 1 & 1 & 5 \\
\hline 9 & $\begin{array}{l}\text { Hashemite Commission for Military } \\
\text { Casualties }\end{array}$ & 0 & 0 & 0 & 0 & 0 & 0 \\
\hline 10 & $\begin{array}{l}\text { Jordan Radio and Television } \\
\text { Corporation }\end{array}$ & 1 & 1 & 1 & 1 & 0 & 4 \\
\hline 11 & Greater Amman Municipality & 1 & 1 & 1 & 1 & 1 & 5 \\
\hline 12 & Central Bank of Jordan & 0 & 0 & 0 & 0 & 0 & 0 \\
\hline 13 & $\begin{array}{l}\text { Petra Development Tourism } \\
\text { Regional Authority }\end{array}$ & 1 & 0 & 0 & 1 & 1 & 3 \\
\hline 14 & Jordan News Agency (Petra) & 1 & 1 & 1 & 1 & 0 & 4 \\
\hline 15 & $\begin{array}{l}\text { Jordan's Economic and Social } \\
\text { Council (ESC) }\end{array}$ & 1 & 1 & 1 & 1 & 1 & 5 \\
\hline 16 & $\begin{array}{l}\text { Economic and social institution of } \\
\text { military retirees }\end{array}$ & 0 & 0 & 0 & 0 & 0 & 0 \\
\hline 17 & $\begin{array}{l}\text { National Resources Investment and } \\
\text { Development Corporation }\end{array}$ & 0 & 0 & 0 & 0 & 0 & 0 \\
\hline 18 & $\begin{array}{l}\text { Authorization Standards for Higher } \\
\text { Education Institutions }\end{array}$ & 1 & 0 & 0 & 1 & 1 & 3 \\
\hline 19 & $\begin{array}{l}\text { National Center for Curriculum } \\
\text { Development }\end{array}$ & 0 & 0 & 0 & 0 & 0 & 0 \\
\hline 20 & $\begin{array}{l}\text { Aqaba Special Economic Zone } \\
\text { Authority }\end{array}$ & 1 & 0 & 0 & 1 & 0 & 2 \\
\hline 21 & The Jordan Securities Commission & 1 & 1 & 1 & 1 & 0 & 4 \\
\hline 22 & General Ifta' Department & 1 & 1 & 1 & 1 & 0 & 4 \\
\hline 23 & $\begin{array}{l}\text { Higher Council for the Right of } \\
\text { Persons with disabilities }\end{array}$ & 1 & 1 & 1 & 1 & 0 & 4 \\
\hline 24 & Jordanian Nursing Council & 1 & 1 & 0 & 1 & 1 & 4 \\
\hline 25 & $\begin{array}{l}\text { The Higher Council for Science and } \\
\text { Technology }\end{array}$ & 0 & 1 & 1 & 0 & 0 & 2 \\
\hline 26 & $\begin{array}{l}\text { Energy and Minerals Regulatory } \\
\text { Commission }\end{array}$ & 1 & 0 & 0 & 1 & 0 & 2 \\
\hline 27 & $\begin{array}{l}\text { The Jordanian Complex for Arabic } \\
\text { Language }\end{array}$ & 1 & 1 & 0 & 1 & 1 & 4 \\
\hline 28 & $\begin{array}{l}\text { Ministry of Higher Education and } \\
\text { Scientific Research }\end{array}$ & 1 & 1 & 1 & 1 & 1 & 5 \\
\hline 29 & The Ministry of Finance & 0 & 0 & 0 & 0 & 0 & 0 \\
\hline 30 & $\begin{array}{l}\text { Ministry of Foreign Affairs and } \\
\text { Expatriates }\end{array}$ & 1 & 1 & 1 & 0 & 0 & 3 \\
\hline 31 & $\begin{array}{l}\text { The Ministry of Industry, Trade, } \\
\text { and Supply }\end{array}$ & 1 & 1 & 0 & 1 & 0 & 3 \\
\hline 32 & Ministry of Interior & 1 & 1 & 0 & 1 & 1 & 4 \\
\hline 33 & The Ministry of Justice & 1 & 1 & 0 & 1 & 1 & 4 \\
\hline
\end{tabular}




\begin{tabular}{|c|c|c|c|c|c|c|c|}
\hline 34 & The Ministry of Municipal Affairs & 0 & 0 & 0 & 0 & 0 & 0 \\
\hline 35 & $\begin{array}{l}\text { Ministry of Planning and } \\
\text { International Cooperation }\end{array}$ & 1 & 1 & 1 & 1 & 0 & 4 \\
\hline 36 & $\begin{array}{l}\text { Ministry of Public Works and } \\
\text { Housing }\end{array}$ & 0 & 0 & 0 & 0 & 0 & 0 \\
\hline 37 & Ministry of Social Development & 1 & 1 & 1 & 1 & 1 & 5 \\
\hline 38 & Ministry of Tourism & 1 & 1 & 0 & 1 & 0 & 3 \\
\hline 39 & Ministry of Transport & 1 & 0 & 0 & 0 & 0 & 1 \\
\hline 40 & Ministry of Water and Irrigation & 0 & 0 & 0 & 0 & 0 & $\overline{0}$ \\
\hline 41 & Ministry of Work & 0 & 1 & 1 & 0 & 0 & 2 \\
\hline 42 & Ministry of Health & 1 & 1 & 0 & 1 & 0 & 3 \\
\hline 43 & Ministry of Agriculture & 0 & 0 & 0 & 0 & 0 & 0 \\
\hline 44 & Ministry of Islamic Awqaf Affairs & 1 & 1 & 1 & 1 & 0 & 4 \\
\hline 45 & $\begin{array}{l}\text { Ministry of Information \& } \\
\text { Communications }\end{array}$ & 1 & 1 & 1 & 1 & 1 & 5 \\
\hline 46 & Ministry of Culture & 1 & 1 & 1 & 1 & 0 & 4 \\
\hline 47 & $\begin{array}{l}\text { Ministry of Energy and Mineral } \\
\text { Resources }\end{array}$ & 1 & 1 & 1 & 1 & 1 & 5 \\
\hline 48 & Ministry of Education & 1 & 1 & 1 & 1 & 1 & 5 \\
\hline 49 & Ministry of Environment & 1 & 1 & 1 & 1 & 1 & 5 \\
\hline 50 & $\begin{array}{l}\text { Ministry of Public Sector } \\
\text { Development }\end{array}$ & 1 & 1 & 0 & 1 & 1 & 4 \\
\hline 51 & $\begin{array}{l}\text { Ministry of political and } \\
\text { parliamentary Affairs }\end{array}$ & 1 & 0 & 1 & 1 & 1 & 4 \\
\hline 52 & Ministry of Youth & 1 & 0 & 1 & 1 & 1 & 4 \\
\hline
\end{tabular}

Table 3: The selected 52 governmental institutions and the three indicators (presence, UTD, and interaction). Source: Prepared by the authors

* The institution has any presence (page, account or channel) on one of the social media platforms.

** The institution's information on social media platforms are within 10 days or less.

*** The institution on social media platforms answered the researcher's question within the research time.

\section{Discussion}

From the results in Table 1 above we can conclude three main results according to the three indicators as the following:

\subsection{Presence}

As we can see in the results above, we found most of the governmental institutions have existence on the three social media websites; just 12 out of 52 institutions did not have any existence on any of the social media platforms and that is the $23 \%$ of all the institutions. (see Figure 1 ) 


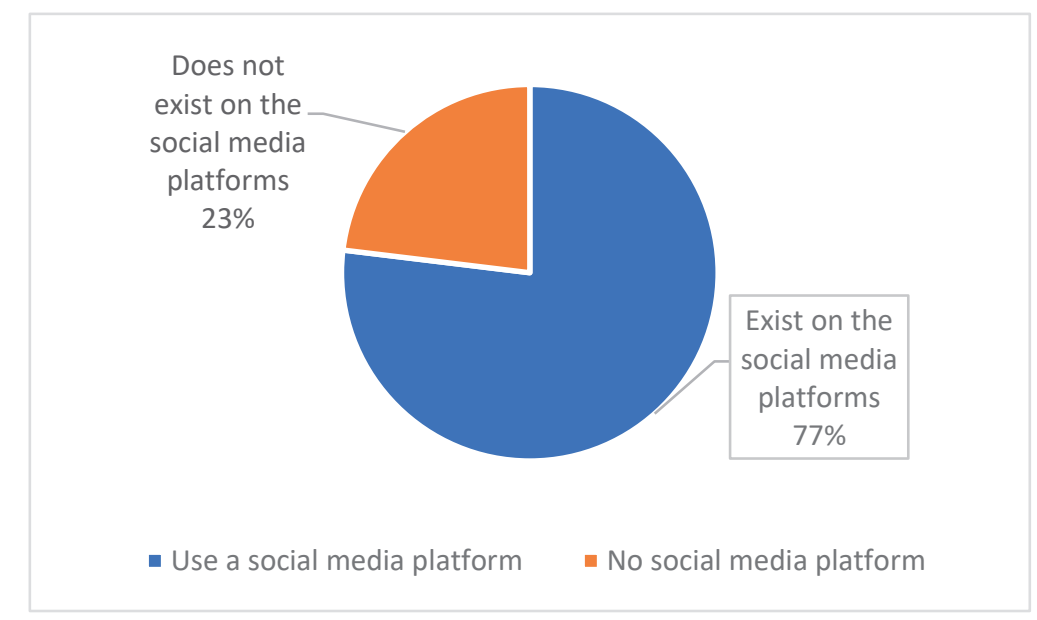

Figure 1: The selected governmental institutions' presence on social media platforms Source: Prepared by the authors

As we have seen $77 \%$ of the institutions have at least one presence on one of the three websites and this is a significant indication that the Jordanian government is aware of the importance of these websites and seek to be present on these platforms. Moreover, from the results, we can see how the governmental institutions' presence distributed between the three social media platforms selected for this study (Figure 2.).

Figure .2 shows clearly that from the three social media platforms Facebook is the most common used by Jordanian institutions with $41 \%$ comparing with the other two websites.

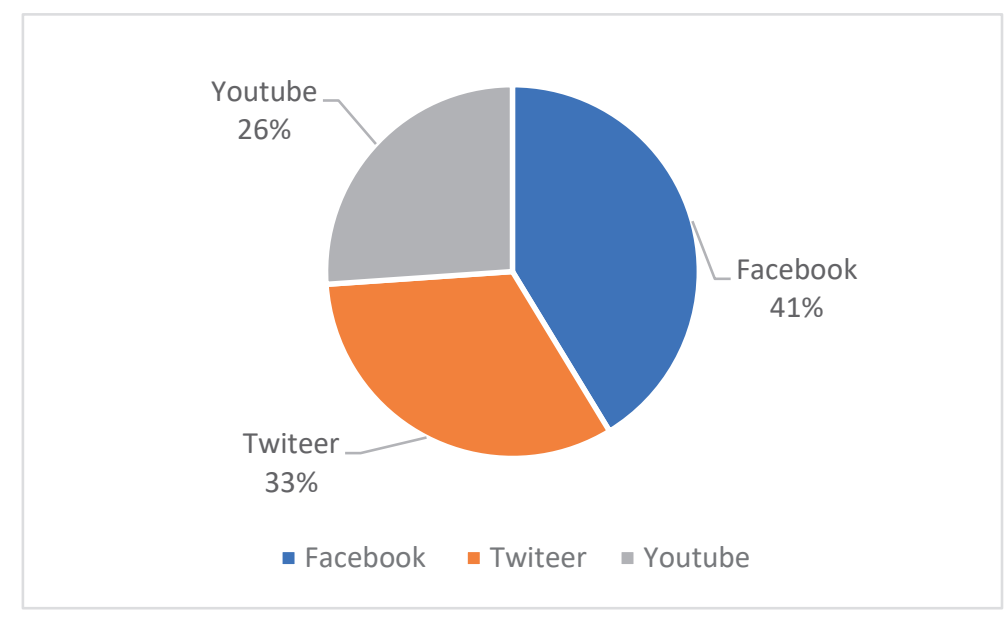

Figure 2: The selected governmental institutions' presence on Facebook, Twitter, and YouTube Source: Prepared by the authors

\subsection{Up to date information (UTD)}

After the social media content has analyzed and checked out if the information published on the institutions' pages and accounts were new information or not, as we mentioned in the methods section before.

The result in the table above shows that most of the governmental institution's social media platforms information (35 institutions) are up to date and always show new information for the citizens, and 
that showed that the Jordanian government knows how important always to publish new information for the citizens and also showed that there is someone or a department who check these platforms and update the information on them. Finally the results showed that only 17 institutions out of 52 are not updating their content regularly as you can see in Figure 3.

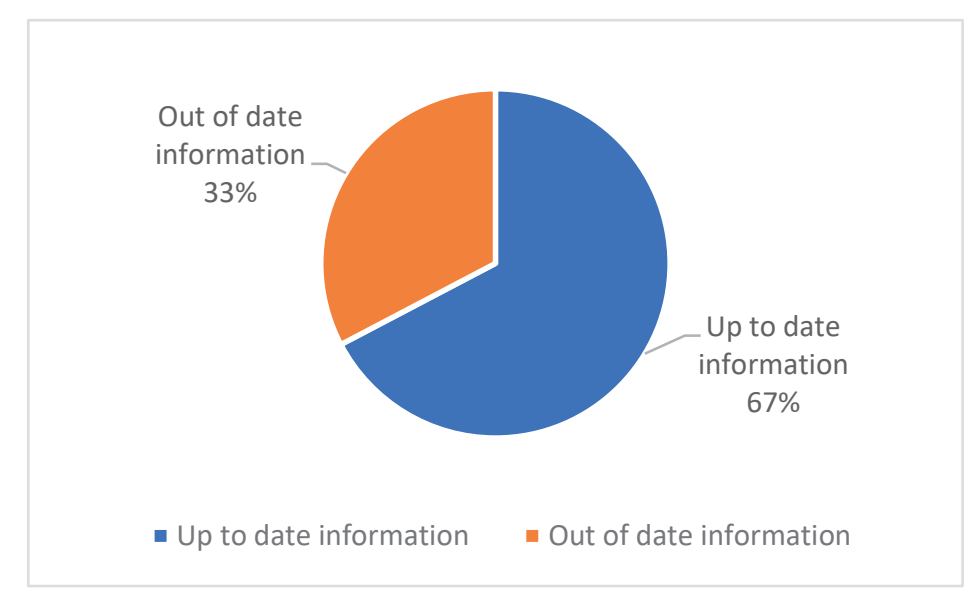

Figure 3: The selected governmental institutions' information up to date Source: Prepared by the authors

\subsection{Interaction}

As we described above, social interaction plays a vital role in government-citizens relationships. To check this criterion as we mentioned before, a question has been sent to their pages and account on social media platforms to check who is going to reply on this question and check the level of interaction.

From the results above we can see that most of the institutions on social media platforms are not so interactive (Figure 4.) and their pages on social media are considered as a one-way information source.

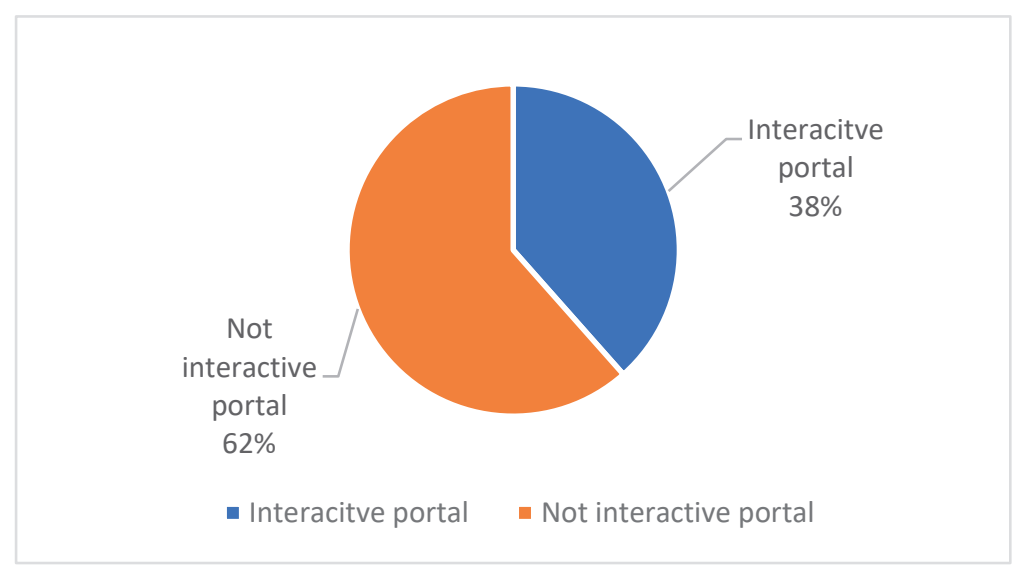

Figure 4: The selected governmental institutions' interaction Source: Prepared by the authors

And finally, we must mention that only 9 institutions out of 52 (the last column in the results table) have fulfilled all the criteria and got 5 , which is full presence on the three social media websites, up 
to date information on their platforms and finally interact with the citizens on their platforms and these institutions are (Civil Service Bureau, Integrity and Anti-Corruption Commission, Greater Amman Municipality, Jordan's Economic and Social Council (ESC), Ministry of Higher Education and Scientific Research, Ministry of Social Development, Ministry of Energy and Mineral Resources, Ministry of Information \& Communications, Ministry of Education and finally Ministry of Environment )

\section{Conclusion}

In conclusion, social media platforms offer a new way for governments to contact their citizens. All the governments around the world, as well as the Jordanian government, try to use these platforms. This paper checked how the Jordanian government uses and deals with the most popular social media platforms (Facebook, Twitter, and YouTube).

After a comprehensive review of the previous literature on this topic in 2 of the largest databases (Scopus and web of science), most of the previous studies indicated the importance of the government's use of social media, due to its positive impact in increasing the E-participation, level of transparency and trust in the government. Some previous studies mentioned some challenges such as the access to the Internet and the technological culture. some Studies have mentioned some challenges for this use, such as the lack of the legal framework, the government's inability to control these platforms, and finally, some studies mentioned some risks related to the effects on privacy and recommended more research on these risks.

The research paper concluded three basic levels of government use of social media, namely presence, updating information and interaction. This paper adopted these three levels and conducted a comprehensive survey of the Jordanian government's use of social media platforms.

From the results, we found that the Jordanian government exists on social media platforms and most institutions (40 out of 52) have a presence on at least one of the three social media websites. Moreover, most of the governmental institutions are updating their pages and accounts and always publish new information (35 out of 52). On the other hand, the interactions with the citizens on these social media platforms are still below the expectations and need to be enhanced (only 20 out of 52), and only 9 governmental institutions fulfilled all the criteria, full presence, up to date information and interaction.

Despite the fact that these platforms exist to offer two-way transactions and contact, the Jordanian institutions are still using these social media platforms as one-way delivery information. Moreover, they still don't have the mechanism to deal with these platforms in the best way to interact with citizens on these platforms and make them more involved in its policies. We can highlight that the Jordanian officials must pay more attention to these important platforms and that this may lead to more success in e-government implications.

Finally, there were limitations in this research and could lead to more future research in this field like taking more criteria into account (technical factors, trust, privacy, etc.), moreover to consider the demand side (the citizens) opinions about the government performance on social media platforms could lead to better understanding. 


\section{References}

[1] AlRYAlat, M. A. A., RANA, N. P., SAHU, G. P., DWIVEDI, Y. K. and TAJVIDI, M., (2019). Use of Social Media in Citizen-Centric Electronic Government Services. In Crowdsourcing (pp. 952-977). https://doi.org/10.4018/978-1-5225-8362-2.ch047

[2] BERTOT, John C., JAEGER, P. T. and GRIMES, J. M., (2010). Using ICTs to create a culture of transparency: E-government and social media as openness and anti-corruption tools for societies. Government Information Quarterly, 27(3), 264-271. https://doi.org/10.1016/j.giq.2 010.03 .001

[3] BERTOT, J. C., JAEGER, P. T. and HANSEN, D., (2012). The impact of polices on government social media usage: Issues, challenges, and recommendations. Government Information Quarterly, 29(1), 30-40. https://doi.org/10.1016/j.giq.2011.04.004

[4] BONSÓN, E., TORRES, L., ROYO, S. and FLORES, F., (2012). Local e-government 2.0: Social media and corporate transparency in municipalities. Government Information Quarterly, 29(2), 123-132. https://doi.org/10.1016/j.giq.2011.10.001

[5] BOSCH, D., (2017). Use of social media and e-Government in disasters: 2016 Louisiana floods case study. Journal of Emergency Management, 15(6), 391-405. https://doi.org/10.5055/jem.2017.0347

[6] BOYD, D. M. and ELLISON, N. B., (2007). Social network sites: Definition, history, and scholarship. Journal of Computer-Mediated Communication, 13(1), 210-230. https://doi.org/10.1111/j.1083-6101.2007.00393.x

[7] BTOUSH, M. H., (2014). Government's presence on social media a study with special reference to Jordan. Research Journal of Applied Sciences, Engineering and Technology, 7(22), 4813-4816. https://doi.org/10.19026/rjaset.7.869

[8] BTOUSH, M. H., (2014). Government's presence on social media a study with special reference to Jordan. Research Journal of Applied Sciences, Engineering and Technology, 7(22), 4813-4816. https://doi.org/10.19026/rjaset.7.869

[9] CAMAY, S., BROWN, L. and MAKOID, M., (2012). Role of Social Media in Environmental Review Process of National Environmental Policy Act. Transportation Research Record: Journal of the Transportation Research Board, 2307(1), 99-107. https://doi.org/10.3141/230711

[10] CHAIEB, C., ACHOUR, H. and FERCHICHI, A., (2018). E-government and social media in tunisia: An empirical analysis. Lecture Notes in Business Information Processing, 325, 173184. https://doi.org/10.1007/978-3-319-97749-2_14

[11] CLARK, J. L., ALGOE, S. B. and GREEN, M. C., (2018). Social Network Sites and WellBeing: The Role of Social Connection. Current Directions in Psychological Science, 27(1), 3237. https://doi.org/10.1177/0963721417730833

[12] DIDIK MADYATMADJA, E. and JULIO KISWANTO, L., (2019). Social Media-Based E- 
Government Application Feature. International Journal of Recent Technology and Engineering, (3), 2277-3878. https://doi.org/10.35940/ijrte.C6036.098319

[13] GAO, X. and LEE, J., (2017). E-government services and social media adoption: Experience of small local governments in Nebraska state. Government Information Quarterly, 34(4), $627-$ 634. https://doi.org/10.1016/j.giq.2017.09.005

[14] GRÖNLUND, Å., (2010). Ten Years of E-Government: The "End of History" and New Beginning. In LNCS (Vol. 6228). Retrieved from https://link.springer.com/content/pdf/ 10.1007/978-3-642-14799-9_2.pdf

[15] Internet world stats. (2017). Middle East Internet Usage Stats and Facebook Statistics. Retrieved March 26, 2018, from https://www.internetworldstats.com/middle.htm

[16] JAEGER, P. T., (2003). The endless wire: E-government as global phenomenon. Government Information Quarterly, 20(4), 323-331. https://doi.org/10.1016/j.giq.2003.08.003

[17] JAEGER, P. T. and Thompson, K. M., (2003). E-government around the world: Lessons, challenges, and future directions. Government Information Quarterly, 20(4), 389-394. https://doi.org/10.1016/j.giq.2003.08.001

[18] KAWTRAKUL, A., MULASASTRA, I., CHANLEKHA, H., RAJBHANDARI, S., PRATHUMCHAI, K., NAGAI, M. and KHUNTHONG, V., (2012). Improving disaster responsiveness using a mix of social media and e-government. KEOD 2012 - Proceedings of the International Conference on Knowledge Engineering and Ontology Development, 423-426. https://doi.org/10.5220/00041734042304 26

[19] KHASAWNEH, R. T. and ABU-SHANAB, E. A., (2013). E-Government and Social Media Sites: The Role and Impact. World Journal of Computer Application and Technology, 1(1), 10 17. https://doi.org/10.13189/wjcat.2013.010103

[20] LEE, A. and LEVY, Y., (2014). The effect of information quality on trust in e-government systems' transformation. Transforming Government: People, Process and Policy, 8(1), 76-100. https://doi.org/10.1108/TG-10-2012-0011

[21] MA, L., (2016). Government website, social media, and citizens' perceptions of corruption: Evidence from chinese cities. Political Scandal, Corruption, and Legitimacy in the Age of Social Media, (December 2016), 185-204. https://doi.org/10.4018/978-1-5225-2019-1.ch008

[22] MAGRO, M. J., (2012). A Review of Social Media Use in E-Government. Administrative Sciences, 2(4), 148-161. https://doi.org/10.3390/admsci2020148

[23] Nations, U., (2014). E-Government: Transformation of Government. United Nations Public Administration Network, 53. Retrieved from http:/unpan1.un.org/intradoc/groups/public/ documents/UN-DPADM/UNPAN042830.pdf

[24] Nations, U., (2018). E-Government Survey 2018.

[25] OVAIS AHMAD, M., MARKKULA, J. and OIVO, M., (2013). Factors affecting e-government 
adoption in Pakistan: a citizen's perspective. Transforming Government: People, Process and Policy, 7(2), 225-239. https://doi.org/10.1108/17506161311325378

[26] PORUMBESCU, G., (2017). Linking Transparency to Trust in Government and Voice. The American Review of Public Administration, 47(5), 520-537. https://doi.org/10.1177/027 5074015607301

[27] RUMMAN, N. A. and SZILÁGYI, R., (2018). Overview of the electronic public services in agriculture in Jordan. Journal of Agricultural Informatics, 9(2), 40-53. https://doi.org/10.17700/jai.2018.9.2.433

[28] SARRAYRIH, M. A. and SRIRAM, B., (2015). Major challenges in developing a successful e-government: A review on the Sultanate of Oman. Journal of King Saud University - Computer and Information Sciences, 27(2), 230-235. https://doi.org/10.1016/J.JKSUCI.2014.04.004

[29] SHAH, B., (2010). Increasing e-Government Adoption through Social Media: A case of Nepal. Journal of Managerial Science, 12(3), 23-39. Retrieved from http://oru.divaportal.org/smash/record.jsf?pid=diva2:372485

[30] Statista. (2019). Number of social media users worldwide 2010-2021. Retrieved March 17, 2020, from Statista website: https://www.statista.com/statistics/278414/number-of-worldwidesocial-network-users/

[31] UNSWORTH, K. and TOWNES, A., (2012). Social media and e-government: A case study assessing Twitter use in the implementation of the Open Government directive. Proceedings of the ASIST Annual Meeting, 49(1). https://doi.org/10.1002/meet.14504901298

[32] VICENTE, M. R. and NOVO, A., (2014). An empirical analysis of e-participation. The role of social networks and e-government over citizens' online engagement. Government Information Quarterly, 31(3), 379-387. https://doi.org/10.1016/j.giq.2013.12.006

[32] We Are Social. (2017). Digital in 2017: Global Overview - We Are Social. Retrieved March 26, 2018, from We Are Social website: https://wearesocial.com/special-reports/digital-in-2017global-overview 